\title{
Biological aging and coronary artery disease
}

\author{
Biyolojik yaşlanma ve koroner arter hastalı̆̆ı
}

Atherosclerotic vascular disease is strongly associated with aging, whether it is peripheral, cardiovascular, or cerebral vascular. There are multiple risk factors involved besides just aging. Cardiac vascular disease can be tested in the event of death (1), coronary artery disease (CAD) (2) or coronary atherosclerotic burden as this reviewed paper did. Aging signs that have been tested most are gray hair, baldness, and earlobe crease, etc. A variety of genetic, metabolic, nutritional, and acquired disorders result in hair color changes (3). In this issue of the Anatolian Journal of Cardiology, Kocaman et al. (4) focuses on two aspects: 1. atherosclerotic burden in cardiovascular disease, and 2. biological rather than chronological aging factors, especially gray hair.

The authors greatly improved their article in response to a suggestion. They explained the lack of women cases in the study, provided the time period of their data collection, described clearly parameters such as hair loss score, xanthelasma, hair thinning, etc. in the section on methods, and ably supported their conclusion that hair whitening score (HWS) is preferable to chronological aging, comparing different HWS to the degree of CAD and others factors.

All these have been well explained at the end. But, yet there are still two aspects that the authors can do to improve this article even more: firstly, smoking is another strongly associated risk factor, but in this article, it showed no significant difference; secondly, there was good correlation of CAD with the degree of gray hair, except at the highest grade: pure white.

Bulpitt et al. (5) observed that smoking was associated with an increase in apparent age over actual age. An observation study by Mosley et al. (6) suggested a link between smoking and gray hair in both men and women and between smoking and baldness in men, without demonstrating a causal link.

Finally, as the authors postulated, a new scoring system of multiple risk factors concerning premature gray hair and biochemical proof of the link between gray hair and vascular atherosclerosis are exciting prospects to be addressed.

Jen Lou Cheng, Shih-Ying Lee*

From Departments of Cardiology and *Neurology, West Garden Hospital, Taipei-Taiwan

\section{References}

1. Glasser M. Is early onset of gray hair a risk factor? Med Hypotheses 1991; 36: 404-11. [CrossRef]

2. Lotufo PA, Chae CU, Ajani UA, Hennekens CH, Manson JE. Male pattern baldness and coronary heart disease: the Physicians' Health Study. Arch Intern Med 2000; 160: 165-71. [CrossRef]

3. Cline DJ. Changes in hair color. Dermatol Clin 1988; 6: 295-303.

4. Kocaman SA, Çetin M, Durakoğlugil ME, Erdoğan T, Çanga A, Çiçek Y, et al. The degree of premature hair graying as an independent risk marker for coronary artery disease: A predictor of biological age rather than chronological age. Anadolu Kardiyol Derg 2012; 12: 00.00

5. Bulpitt CJ, Shipley MJ, Broughton PM, Fletcher AE, Markowe HL, Marmot MG, et al. The assessment of biological age: a report from the Department of Environment Study. Aging Clin Exp Res 1994; 6: 181-91.

6. Mosley JG, Gibbs AC. Premature grey hair and hair loss among smokers: a new opportunity for health education? BMJ 1996; 313 : 1616. [CrossRef]

Address for Correspondence/Yazışma Adresi: Shih-Ying Lee, MD, Department of Neurology, West Garden Hospital 270, Section 2, Siyuan Rd., 108 Taipei-Taiwan Phone: 886-933154130 E-mail: cyclee1688@gmail.com 